\title{
SUPERVISI SEBAGAI PENINGKAT KUALITAS PENDIDIKAN NASIONAL
}

\author{
SUKMA \\ Email : $\underline{\text { sukma980513@gmail.com }}$
}

\begin{abstract}
Abstrak
Kualitas dari pembelajaran sangat dipengaruhi oleh kualitas dari kinerja guru. Jadi dalam meningkatkan kemampuan untuk melakukankan proses belajar mengajar, perlu perhatian dari lembaga pendidikan yang bertanggungjawab secara terus menerus. Supervisi dapat dilakukan dengan teknik (1) mengunjungi kelas, (2) mengunjungi sekolah, (3) mengadakan ujian dadakan, (4) melakukan konfrensi kasus, (5) melakukan observasi dokumen, (6) menggunakan teknik wawancara, (7) menggunakan angket, dan (8) tahap laporan. Tugas dari seorang supervisor (kepala sekolah) adalah mendorong, membantu dan memberikan keyakinan kepada guru. Supervisi dilakukan melalui banyak tahap penyelesaian masalah belajar mengajar dan tujuannya adalah supaya dapat meningkatkan proses pembelajaan.
\end{abstract}

Kata Kunci: Kualitas, Kinerja Guru, Pendidikan, Supervisi

\section{Latar Belakang}

Menurut maralih dalam jurnalnya yang berjudul Peranan Supervisi Dalam Peningkatan Kualitas Pendidikan Sekolah adalah lembaga pendidikan formal yang terencana dan strategis yang bertujuan untuk mampu dalam meningkatan kualitas pendidikan. Maka diperlukan peningkatan kualitas SDM di sekolah yaitu supervisor dan pendidik.

Kesuksesan pendidikan di sekolah ditentukan oleh pendidik, karena pendidik adalah sebagai fasilitator dan sekaligus sebagai pusat pembelajaran. Kegiatan guru sebagai pendidik menjadi pijakan dalam mencapai tujuan pendidikan dalam sekolah. Apapun yang dilakukan guru dalam proses belajar mengajar , memberikan pengaruh terhadap proses pembelajaran.

Menurut Arifin (Arifin 2000:56) guru dikatakan profesional atau tidak, dilihat apabila guru tersebut memiliki (1) Ilmu pengetahuan yang kuat (2) menguasai kiat-kiat profesi (3) kematangan profesional (4) memiliki kepribadian yang bagus (5) keterampilan.

Tercapainya pendidikan yang bermutu diperlukan guru yang memiliki kompetensi atau memenuhi syarat yaitu professional dan berkulitas. Menurut Glasser pendidik yang kompeten itu adalah (1) menguasai bahan pelajaran, (2) mampu menduga tingkah laku siswa, (3) mampu melaksanakan pengajaran, (4) mampu menilai atau mengevaluasi proses belajar siswa.

Dalam melaksanakan tugas, seorang guru memerlukan pembimbing supaya dapat mengembangkan kemampuannya dalam proses pembelajaran. Dalam hal itu guru memerlukan bimbingan dari seorang supervisor. Supervisi merupakan proses yang dirangkai secara khusus guna membantu guru dalam 
melaksanakan tugas di sekolah agar dapat mengaplikasikan pengetahuan dan keterampilan untuk layanan yang lebih baik pada siswa.

Kenyataannya dalam pelaksanaan supervisi, pimpinan dan pendidik kurang terlaksana. Terlihat dari masih banyak pendidik yang tidak bias meningkatkan kualitas para siswa. Hal ini dapat mengganggu proses belajar mengajar di sekolah. Maka saat sekarang ini perlu dilakukan supervise terhadap guru oleh kepala sekolah yang sebagai supervisor. Dalam kegiatan tersebut hasilnya diharapkan agar guru tersebut lebih berkualitas atau bermutu agar pendidikan di sekolah membaik dan dapat mewujudkan tujuan pendidikan nasional. Permasalahan lain yang terjadi adalah masih rendahnya kualitas pimpinan dalam melaksanakan supervisi terhadap pendidikan.

\section{Supervisi}

Menurut Ahmad Sabandi dalam jurnalnya yang berjudul Supervisi Pendidikan Untuk Pengembangan Profesionalitas Guru Berkelanjutan bahwa Supervise pendidikan berkembang seiring berkembangnya zaman. Seperti pengetahuan, teknologi, sosial ekonomi dan budaya yang ada dalam masyarakat.

Supervisi pendidikan yaitu usaha mendorong, mengatur dan membimbing secara berkelanjutan pertumbuhan guru di sekolah agar penidik paham dan lebih efisien dalam mewujudkan semua fungsi pengajaran dan mereka dapat memantau dan membimbing pertumbuhan peserta didik, sehingga mereka mampu dan lebih kompeten berpartisipasi dalam masyarakat.

Supervisi dapat diartikan kegiatan yang dilakukan pengawas dan pimpinan sebagai pejabat yang lebih tinggi dari guru untuk rnemantau atau mengawasi pekerjaan pendidik (guru).

Supervisi juga dapat diartikan sebagai kegiatan kepala sekolah yang dilakukan untuk tujuan perbaikan proses belajar mengajar di sekolah. Terdapat dua tujuan yang harus diwujudkan oleh supervisor, yaitu (1) perbaikan pada pendidik dan peserta didik, (2) meningkatkan mutu pendidikan.

\section{Kegiatan Supervisi}

Kegiatan supervisi bertujuan untuk menjaga dan melindungi kualitas seorang pendidik dalam proses belajar mengajar di sekolah. Kegiatan supervise penting jika ingin kualitas pendidikan yang lebih baik di sekolah, karena supervisi merupakan pertolongan terhadap guru. Tujuan dari supervisi adalah memberikan pelayanan dan pertolongan untuk memperbaiki kualitas mengajar pendidik di kelas. Tujuan supervisi pendidikan bagi supervisor adalah untuk membantu pendidik di sekolah supaya mampu menjalankan tugas sebagai tenaga pendidik secara menyeluruh untuk menghasilkan situasi pembelajaran yang lebih efektif dan efisien.

Fungsi supervisi pendidikan meliputi empat fungsi utama yaitu (1) penelitian, (2) penilaian, (3) perbaikan, dan (4) peningkatan. Supervisi yang dijalankan berkaitan dengan tugas profesional pendidik yaitu (1) keahlian dalam 
merencanakan pengajaran, (2) keahlian dalam mengimplementasikan pengajaran, dan (3) keahlian dalam menilai pembelajaran.

Ada beberapa prinsip yang perlu diperhatikan dalam melakukan supervisi pendidikan yaitu: (1) ilmiah, (2) demokrasi, (3) kooperatif, (4) konstruktif dan kreatif.

\section{Pelaksanaan Supervisi}

Supervisi dilaksanakan oleh pengawas, kepsek, wakepsek, bidang kurikulum atau akademik, walas, petugas BK, dan petugas perpustakaan, dan inti supervisi adalah guru dan pegawai.

Yang menjadi tujuan utama supervisi pendidikan adalah guna melakukan bimbingan terhadap pendidik agar bisa melakukan tugas dengan baik. Supervisor harus bisa mengendalikan dan mensupervisi terhadap tenaga kependidikan dengan tujuan meningkatkan profesional guru dan kualitas pembelajaran.

Ada beberapa teknik supervisi yang dapat digunakan supervisor yaitu (1) teknik kunjungan sekolah, (2) teknik kunjungan kelas, (3) teknik kuis dadakan, (4) teknik konfrensi kasus, (5) teknik observasi dokumen, (6) teknik wawancara, 7) teknik angket, 8) teknik laporan. Kepala sekolah melakukan supervisi terhadap guru meliputi (1) masalah profesional guru, (2) masalah kehadiran dan kegiatan guru, (3) masalah kematangan mengajar guru, (4) Masalah pencapaian tujuan dari pelaksanaan ekstrakurikuler, (5) penguasaan bahan ajar. kegiatan supervisi yang dilakukan oleh seorang supervisor adalah merencanakan program, melaksanakan supervisi dan menindak lanjuti supervisi.

\section{Upaya Meningkatkan Supervisi}

Kepala sekolah diharapkan dapat menyusun program supervisi yang dapat memberikan bimbingan kepada pendidik agar mereka dapat memperbaiki dirinya sendiri baik dalam segi pengajaran atau teknik pengajaran dan kualitas wawasan pengetahuan mendasar pendidik. Supervisi dasarnya melakukan pengawasan terhadap proses pendidikan di sekolah. Supervisi masuk ke dalam interaksi kepala sekolah dengan pendidik di dalam kegiatan proses belajar mengajar. Meningkatkan kualitas diri guru dapat dilaksanakan melalui layanan supervise yang diberikan supervisor atau kepala sekolah.

Program supervisi seharusnya memberikan perubahan dalam kegiatan pengajaran. Perubahan dapat dilakukan melalui berbagai usaha dalam pengembangan kurikulum, kegiatan pendidikan dan pelatihan dalam jabatan untuk pendidik. Pimpinan harus menguasai prosedur dalam pelaksanaan supervise, khususnya supervisi pengajaran beserta tujuannya. Supervisi juga sebagai suatu bentuk usaha dalam memberikan pelayanan perbaikan situasi mengajar belajar . Supervisi dari kepala sekolah harus diarahkan guna memberikan bantuan dan bimbingan serta pembinaan kepada pendidik supaya mereka mampu bekerja lebih baik dalam membimbing pelajarnya dan mensukseskan pendidikan agar tercapainya tujuan pendidikan nasional.

\section{Kesimpulan}


Sekolah adalah lembaga pendidikan formal yang terencana dan strategis yang bertujuan untuk mampu dalam meningkatan kualitas pendidikan. Kesuksesan pendidikan di sekolah ditentukan oleh pendidik, karena pendidik adalah sebagai fasilitator dan sekaligus sebagai pusat pembelajaran. Kegiatan guru sebagai pendidik menjadi pijakan dalam mencapai tujuan pendidikan dalam sekolah. Apapun yang dilakukan guru dalam proses belajar mengajar , memberikan pengaruh terhadap proses pembelajaran.

Supervisi juga dapat diartikan sebagai kegiatan kepala sekolah yang dilakukan untuk tujuan perbaikan proses belajar mengajar di sekolah. Terdapat dua tujuan yang harus diwujudkan oleh supervisor, yaitu (1) perbaikan pada pendidik dan peserta didik, (2) meningkatkan mutu pendidikan. Kegiatan supervisi bertujuan untuk menjaga dan melindungi kualitas seorang pendidik dalam proses belajar mengajar di sekolah. Kegiatan supervise penting jika ingin kualitas pendidikan yang lebih baik di sekolah, karena supervisi merupakan pertolongan terhadap guru. Tujuan dari supervisi adalah memberikan pelayanan dan pertolongan untuk memperbaiki kualitas mengajar pendidik di kelas.

Supervisi dilaksanakan oleh pengawas, kepsek, wakepsek, bidang kurikulum atau akademik, walas, petugas BK, dan petugas perpustakaan, dan inti supervisi adalah guru dan pegawai. Yang menjadi tujuan utama supervisi pendidikan adalah guna melakukan bimbingan terhadap pendidik agar bisa melakukan tugas dengan baik. Supervisor harus bisa mengendalikan dan mensupervisi terhadap tenaga kependidikan dengan tujuan meningkatkan profesional guru dan kualitas pembelajaran.

\section{Saran}

Kepala sekolah diharapkan dapat menyusun program supervisi yang dapat memberikan bimbingan kepada pendidik agar mereka dapat memperbaiki dirinya sendiri baik dalam segi pengajaran atau teknik pengajaran dan kualitas wawasan pengetahuan mendasar pendidik. Supervisi dasarnya melakukan pengawasan terhadap proses pendidikan di sekolah. Supervisi masuk ke dalam interaksi kepala sekolah dengan pendidik di dalam kegiatan proses belajar mengajar. Meningkatkan kualitas diri guru dapat dilaksanakan melalui layanan supervise yang diberikan supervisor atau kepala sekolah.

\section{References}

Maralih. (2014). Peranan Supervisi Dalam Peningkatan Kualitas Pendidikan. Jurnal Qathrunâ, 1(1), 179-192.

Sabandi, A. (3013). Supervisi Pendidikan Untuk Perkembangan Profesionalitas Guru Berkelanjutan. Jurnal Ilmiah Ilmiah Ilmu Pendidikan, XIII(2), 1-9. 